\title{
USING SOIL MOISTURE OBSERVATIONS TO CHARACTERIZE KARST GROUNDWATER RECHARGE PROCESSES AT FIVE CONTRASTING CLIMATE REGIONS
}

\author{
Romane Berthelin \\ Chair of Hydrological Modeling and Water Resources, Freiburg University, Friedrichstrasse 39, Freiburg, 79098, \\ Germany,romane.berthelin@hydmod.uni-freiburg.de
}

Mirjam Scheller

Chair of Hydrological Modeling and Water Resources, Freiburg University, Friedrichstrasse 39, Freiburg, 79098, Germany,mirjam.scheller@gmx.de

\section{Justine Berg}

Chair of Hydrological Modeling and Water Resources, Freiburg University, Friedrichstrasse 39, Freiburg, 79098, Germany,bergjus94@gmail.com

\section{Andreas Hartmann}

Chair of Hydrological Modeling and Water Resources, Freiburg University, Friedrichstrasse 39, Freiburg, 79098, Germany,andreas.hartmann@hydmod.uni-freiburg.de

\begin{abstract}
Karst groundwater constitutes a considerable fraction of drinking water in many regions in the world. Understanding its recharge processes is important for a sustainable water resource management. Experimental approaches to study karst aquifers mostly focus on the characterization of the entire aquifer using the disintegration of its output signal measured at the spring. Despite the important role of the soil and epikarst for recharge processes, limited attention has been given to this specific part of the systems. In our study, we present the first results of a soil monitoring program at five representative locations across the globe. We use a large number of soil moisture observations to understand the partitioning of rainfall into infiltration, storage, evapotranspiration, and groundwater recharge at five contrasting climates and two different land use types (forest $\&$ grassland).
\end{abstract}

With the present analyses, almost no differences were identified between the two land use types investigated. However, the site with the largest number of soil moisture measurements creating recharge is the one with a tropical climate as expected, as the one with the lowest number is the semi-arid site. However, other sites with different climate conditions like oceanic and Mediterranean show similar results. Other parameters influencing recharge processes should be investigated in the future.

\section{Introduction}

Around a quarter of the world's population is dependent on drinking water from karst aquifers (Ford and Williams, 2013). The water storage in these systems is significantly affected by climate change, land use changes and a growing population (Wada et al., 2010; Vörösmarty et al., 2010). It is therefore essential to study the water storage and hydrological processes in these systems. This poses a challenge especially in karstic areas since karstification leads to high heterogeneity influencing variable pathways and velocity (Goldscheider and Drew, 2007).

Several experimental methods have been conducted in order to characterize karst systems. One of the most popular methods used to investigate flow paths and flow times through karst systems is the analysis of signals of artificial and natural tracers at karst springs (Mudarra et al., 2014; Goldscheider et al., 2008). Besides, natural tracers are used to study the transit time and dispersion of water entering the karst system (Maloszewski et al., 2002). Hydraulic methods like pumping test are conducted in order to analyze the heterogeneity of hydraulic conductivities (Giese et al., 2018). These approaches are mainly focused on the characterization of the entire aquifer. The investigation on the role of the vadose zone in water recharge and its processes has received limited attention (Berthelin and Hartmann, 2020).

The vadose zone is composed of the soil, the top weathered carbonate rock called epikarst (Williams, 1983) and 
the unsaturated carbonate rock. Dissolution processes lead to an irregular interface between soil and rock and the porosity of the rock decreases with depth. These characteristics lead to different hydrodynamic processes. The soil influences infiltration velocity and mixing processes (Charlier et al., 2012; Perrin et al., 2003) while the water in the shallow subsurface is additionally subject to evapotranspiration. The heterogenic interface between the soil and the weathered carbonate rock leads to a redistribution of infiltrated water (Fu et al., 2015; Hartmann and Baker, 2017). Likewise, the heterogeneity at the interface of the weathered and non-weathered rock can lead to the formation of perched aquifers and therefore to lateral redistribution of water flow through enlarged fractures (Williams, 1983). There are several other ways in which the vadose zone affects recharge processes. The soil and rock properties like porosity, fractures, lithology, karstification, etc., as well as the epikarst topography have major impacts on recharge processes and therefore on the water storage. The thickness of the subsurface affects water flow velocity since a shallow epikarst has a higher proportion of large fractures (Zhang et al., 2013). Precedent moisture conditions have an effect on storage capacity, infiltration rate since more water can be stored, and subsurface flows are less important under dry conditions (Charlier et al., 2012; Fu et al., 2015; Trček, 2007). Finally, evaporation rates, weathering and dissolution processes are influences by vegetation and climate (Sarrazin et al., 2018).

In this study, we present the first results of a soil moisture monitoring network to characterize karst recharge and evapotranspiration processes that was installed at five different climate regions. Measurements of soil moisture are conducted at a high spatial and temporal resolution. They will be used to quantify the influence of land cover types, soil and epikarst heterogeneity on spatiotemporal dynamics of karstic recharge under different climate conditions.

\section{The Monitoring Concept}

The experimental concept is designed to investigate the influence of soil and epikarst heterogeneities on water flow and storage processes in the karst vadose zone, and to observe the impact of land cover type and climate on the karst system recharge and evapotranspiration. To address these objectives, we want to use standardized observations of soil moisture (Ries et al., 2015). Five sites with different climatic conditions were selected: tropical climate, Mediterranean, humid oceanic, humid mountainous and semi-arid climate (Figure 1).

\section{Description of Sites}

All of the selected sites are located at carbonate rock regions that have local or regional relevance for water resources management; they differ however in their surface and subsurface characteristics. The following part is dedicated to the description of the sites. However, more detailed descriptions of the sites can be found in Berthelin et al., 2019, as well as the detailed soil profiles description of each plot.

\section{Puerto Rico (PR)}

El Tallonal is located north of Puerto Rico in the karstic zone of a private natural reserve. With an annual average temperature of $25.5^{\circ} \mathrm{C}$ and an annual precipitation of $1295 \mathrm{~mm}$, the area is classified as a tropical climate (Af). Vegetation in the reserve is categorized as a subtropical moist forest zone with exotic plants as Castilla elastica $(S$.) and native plants such as Guarea Guidonia (L.) (Fonseca da Silva, 2014; Rivera-Sostre, 2008). The main geological units found in the studied area are limestones from the late Oligocene and early Miocene (Seiglie and Moussa, 1984; Behrensmeyer et al., 1992). These formations respectively called Aymamón and Aguada show characteristic features of karst like deep dolines which are separated by high hills called mogotes (Lugo et al., 2001). One of the most productive groundwater resources of the island lies in the upper layer of northern limestone of the Aymamón and Aguada formation. It is recharged by precipitation, surface streams and runoff. The recharge in the mogotes area is mainly due to runoff during large precipitation events (Troester, 1999).

The soil of the Tollonal karstic area is, according to the classification of Puerto Rico' soil, a humid oxisol with minimal and simple development of horizons (Beinroth et al., 2003). The clayey texture of the soil leads to a high water retention capacity. Besides, the soil shows moderate fertility and high acidity whereof growth can be limited (Viera et al., 2008). At the grassland plot, the bed rock cannot be reach since the soil profile can have a thickness of up to 9 meters as reported from the landowner. At the forest plot, a dense network of roots can be found in the first $30 \mathrm{~cm}$ of the soil.

\section{Spain (ES)}

Villanueva del Rosario system is a part of the Sierra Camarolos and Sierra del Jobo aquifer. It is located $30 \mathrm{~km}$ north of the city of Malaga in Spain, with a catchment area of $14 \mathrm{~km}^{2}$ and a range of altitudes from 600 to $1640 \mathrm{~m}$ 


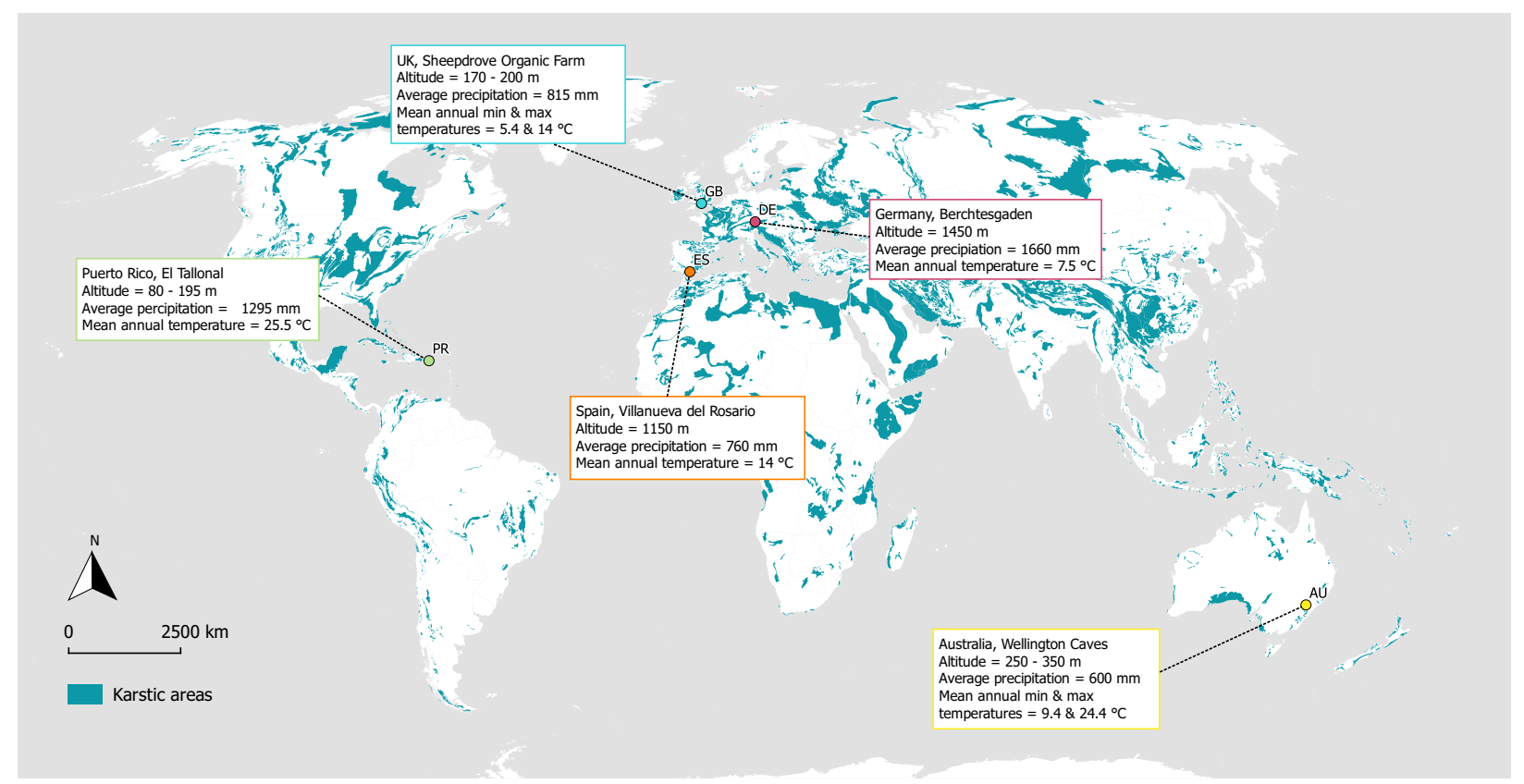

Figure 1. Location of the five sites and their main characteristics. Carbonate rock outcrops derived from the World Karst Aquifer Map (Chen et al., 2017).

(Marín et al., 2015). The climate is classified as Mediterranean climate (Csa) with an average annual temperature around $14^{\circ} \mathrm{C}$ at $700 \mathrm{~m}$ and a mean annual precipitation below $600 \mathrm{~mm}$ in lower altitudes and more than $900 \mathrm{~mm}$ in higher altitudes. The vegetation is Mediterranean scrubland with Mediterranean forest patches and pines from reforestation (Marín et al., 2015). The geology of the area is carbonate rocks from the Jurassic with a maximum thickness of $450 \mathrm{~m}$ (Peyre, 1974). The aquifer is bounded at almost all its tectonic borders by Upper Triassic clays and evaporate, Flysch clays and sandstones and Cretaceous-Paleogene marls, and presents a high fracturation and karstification degree (Mudarra et al., 2014). The spring draining the system is located at the north border of the karst system at an altitude of $770 \mathrm{~m}$. With an annual mean flow discharge of $260 \mathrm{~L} / \mathrm{s}$ it reacts rapidly to precipitation events (Mudarra et al., 2014).

In the study area, two main soil types are found: patchy leptosols, which is a shallow soil with a thickness up to $30 \mathrm{~cm}$ and soil with a silty, clayey texture ranging in depth from 10-70 cm (Marín et al., 2015).

According the description conducted in the field, the soil at the plots is silty and became more clayey with the depth. More roots and deeper are found in the soil at the forest than in the grassland area.

\section{United Kingdom (GB)}

The United Kingdom site is located on the property of the Sheepdrove Organic Farm, in south England at the West Berkshire Downs. The climate of this site is classified as Oceanic with an annual minimum and maximum temperature of $5.4^{\circ} \mathrm{C}$ and $14.0^{\circ} \mathrm{C}$. The annual average precipitation is $815 \mathrm{~mm}$. The vegetation covering the sites is made of meadow and forest with species as beech trees, hawthorn bushes, cherry trees and maples (Iwema, 2017). The study area is located in the Lambourn catchment area, where the main aquifer of the region is situated. The groundwater table lies at tens of meter depth (Wheater et al., 2007; Rahman and Rosolem, 2017). The geology of the area is Chalk of Upper Cretaceus age (Wheater et al., 2007), which is highly permeable and karstified.

The soil of the study area is described in Iwema 2017 as grey loamy soil with flints and pieces of white chalk. The chalky bedrock in the grassland can be found at all location between $30 \mathrm{~cm}$ and $60 \mathrm{~cm}$ depth. In the forest, the chalk layer can be found between 10 am and $35 \mathrm{~cm}$. Thick roots are present in the entire soil depth at most of the profile.

\section{Germany (DE)}

The Berchtesgaden Land site is part of a National Park located in the Alps in Southeast Germany. With an average 
temperature of $7.5^{\circ} \mathrm{C}$ and an annual average precipitation between 1500 and $2600 \mathrm{~mm}$, depending on the altitude, the climate is classified as humid continental climate (Dfb). The altitude of the national park ranges between 603 and $2713 \mathrm{~m}$. The type of vegetation found in the park is grass, mountain pine and green alder shrubs (Garvelmann et al., 2017). Besides the dominant geological formations Triassic Dachstein limestone and Ramsau dolomite, there are Jurassic and Cretaceous rock series present. Karst features like sinkholes, dry streams and caves can be found in the area. The karst system is drained by 330 springs which are located at the interface of limestone and dolomite rock and have a vast variability in their discharge (Kraller et al., 2011). The study site is situated at $1450 \mathrm{~m}$ of altitude with an annual precipitation of $1660 \mathrm{~mm}$. In the colder season from November to the end of April or beginning of May, a snow cover can be found in the area.

There are three main different soil types in the national park: Syrosem (35.5\%), Cambisol (30.1\%) and Podsol (26.7\%) (Garvelmann et al., 2017). In the plots, the soil has a texture varying from silty to clayey. A rocky layer with limestone rock pieces at the bottom of the soil is observed. At the grassland plot, roots are mainly observed at the upper $\sim 0-15 \mathrm{~cm}$ of the soil. At the forest plot, roots are abundant in most of the entire profiles.

\section{Australia (AU)}

The Wellington Caves site is located in a reserve on the eastern side of the Catombal Range, adjacent to the Bell River valley and alluvial aquifer, at $7.3 \mathrm{~km}$ south of the town of Wellington. The temperature at the site ranges from $0-45^{\circ} \mathrm{C}$ and the annual mean is $24.3^{\circ} \mathrm{C}$. With an annual rainfall of $620 \mathrm{~mm}$ and PET of $1800 \mathrm{~mm}$, the climate can be classified as temperate semi-arid (Bsh) (Markowska et al., 2016). The vegetation is dominated by the native Australian Grassy White Box Woodland. The deep-water marine sediments of the Ordovician Oakdale formation and the limestone of the middle Devonian Garra formation make up the geology of the reserve. Both the forest and grassland sites are situated on the massive limestone. There are no permanent streams besides the Bell River which flows $700 \mathrm{~m}$ west of the caves and has a high potential connectivity with the aquifer (Keshavarzi et al., 2017). Certain condition need to be met for a recharge of the aquifer according to (Jex et al., 2012). The rainfall needs to be at least $60 \mathrm{~mm}$ within 24-48 hour period depending on soil moisture conditions.
The soil at the study site is extremely dry. At the grassland, most roots are present in the first $\sim 5 \mathrm{~cm}$ of the soil. Deeper horizons show a sandy clay texture, followed bellow by carbonate rock. The soil of the forest site contains partly degraded organic matter in the first $\sim 5 \mathrm{~cm}$ and is clayey with thicker roots. Bellow $20 \mathrm{~cm}$ an increasing amount of rocks can be found indicating the beginning of carbonate rock.

\section{Selection of Plots and Set Up}

At each site, two squares with an area of $400 \mathrm{~m}^{2}$ were selected. One is located in a grassland area, the other one in a forest. GIS analysis and Digital Elevation Models were used in order to choose two plots with a similar slope and exposure within the site. For the soil moisture measurements, 15 locations within each plot were randomly chosen for the installation of soil moisture profiles. Each soil moisture profile was equipped with probes at three different depths in the ground: $5 \mathrm{~cm}, 10 \mathrm{~cm}$ and a deeper depth at the limit between soil and epikarst. In the cases where the epikarst wasn't reached, the third probe was installed at the maximum depth possible $(>80 \mathrm{~cm})$. In total, around 90 soil moisture probes were installed at each site. More details can be found in Berthelin et al (2019).

\section{Results}

Figure 2 shows the dynamics of soil moisture at each site (PR, ES, GB, DE, AU), depending on the land cover (grassland and forest) for the period of July 2018 to March 2019. At the German site, snowfall can present between November and April. No data is available for July 2018 at Puerto Rico as the probes were installed in August 2018.

We can observe that the reaction of soil moisture after precipitation events is different at the different sites (Figure 2). The Puerto Rican and German site present an amplitude of soil moisture values quite high compared to the other sites. Also, the amplitude of reaction of soil moisture to rainfall is different among the sites. The peaks of reaction seem larger at the Australian site, and smoother at the German site. A seasonality can be observed at some of the sites. At Puerto Rico, the amplitudes of reaction are smoother during the months of November to March. This effect is stronger in the forest than in the grassland. At the Spanish site, no soil moisture reaction is observed during the months of July to September, and an increase of general soil moisture value is observed for the rest of the observation period. At the English site, compared to the rest of the time series, the soil moisture 


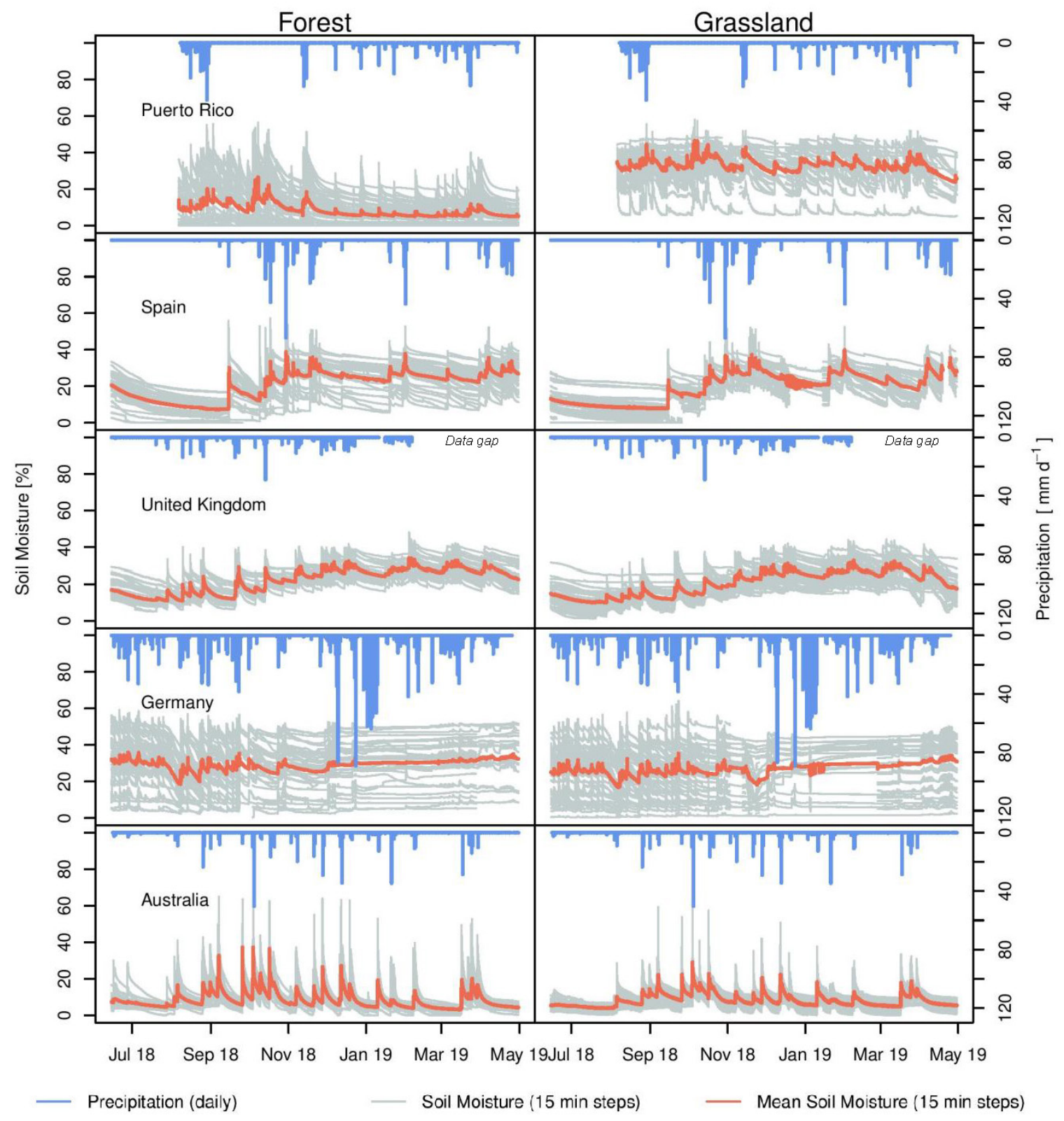

Figure 2. Soil moisture measurement time series recorded at different depths at each site for two different land covers and precipitation.

peaks are larger from July to November. In addition, the amplitude of soil moisture values between the probes is higher during the period between November to May. At the German site, there is almost no soil moisture reaction between December to May, despite the precipitation events that occurred during this period, which indicates snowfall and storage of rainfall within the snow cover. At the Australian site, no soil moisture events at all seem to be recorded during the month of July.
To further understand the different soil moisture patterns among the sites, we consider two seasons (one from October to March, a second one from April to September) separately. In order to identify periods of recharge, we assume that recharge is most probable to occur at soil moisture conditions close to saturation. Accounting for variability of soil porosity within and among our sites, we define a range of $35 \%$ to $65 \%$ of soil moisture, at which we expect a higher probability of groundwater 
recharge. This range corresponds to the possible range of porosities found at loamy soils that developed over carbonate rock (Kirn et al., 2017).

Comparing soil moisture variability among the sites for both seasons shows that the Spanish site and the English site soil moisture median value seems to be similar, lower than at the German site but much higher than at the Australian site (Figure 3). Their forest and grassland values are similar at each site. Only the Puerto Rican site presents different behaviour. Its soil moisture values are lower in the forest than in the grassland. The forest values are as low as at the Australian site, but the values of soil moisture in the grassland are higher than at all the other sites.

The comparison between the seasons allows identifying different site-dependent patterns. At the Puerto Rican site, the soil moisture median value is similar between the two seasons at the forest plot. At the grassland plot, it is slightly higher in the season October-March than during the season April-September and it is the highest value compared to the other sites. At the Spanish site, the median is higher during the season of October to March than during the season April-September, at both forest and grassland sites. At the English site, the median is also higher during the first season compared to the second one at both plots. Its soils moisture median value is similar to the Spanish site but the dispersion of its data is lower. The German site presents a soil moisture median value similar between the two seasons at both plots. It is the site presenting the higher median value at the forest plot and the higher data dispersion at both plots. The median value at the Australian site is almost similar at both seasons at the forest plot and higher during the season October-March than during the season April-September at the grassland plot. This site presents the lower range of variability in its data.

Considering the soil moisture values expected to create recharge, only the grassland site of Puerto Rico presents a median reaching the minimum value, $35 \%$. Then comes the German site where recharge seems to be able to occur more often than at the other sites, at every season at both the grassland and the forest. At the English and Spanish sites, not a lot of soil moisture values reach the threshold, with a slightly higher occurrence during the season October-March. The site presenting the lowest number of value reaching the threshold is the Australian site, for both plots and seasons.

\section{Discussion}

At the Puerto Rican site, a clear difference appears between forest and grassland: the soil moisture in the forest is much lower than in the grassland. This observation is coherent as the roots in this forest site are very abundant and the soil not so much present. The forest soil moisture is, in fact, the lower value compare to all the other sites, but the grassland soil moisture is the highest. At the Spanish site, the summer season is very dry: no precipitation event and so no soil moisture events were recorded. That is why it presents a higher soil moisture value during the season October-March. Grassland and forest values are similar. The English site also presents a higher soil moisture value during the season October-March with similar values between grassland and forest. The soil moisture values are similar to the Spanish ones. This is surprising regarding their different climates. The German site presents the highest amplitude between probes values. No soil moisture reactions were observed during the wintertime despite precipitation events. This is due to the snowfall period and no melting during this time. As the Puerto Rican forest plot has low soil moisture values, the German forest plot is the one with the highest soil moisture median values. The Australian site presents the lowest soil moisture median values, at both grassland and forest (similar to the forest in Puerto Rico's site). The grassland and forest plots present similar values.

Consequently, with the present analysis, the influence of land use cannot be identified among almost all sites except for the site of Puerto Rico. This is the site that present the highest soil moisture values at the grassland plot and this is coherent with the climate conditions. As the Australian site presents the lowest values. Indeed, the site that presents more soil moisture measurements reaching the threshold to initiate recharge is the grassland in Puerto Rico. The site presenting the lower soil moisture measurements reaching the threshold is the one in Australia. The differences between the forest and grassland plots of Puerto Rico can be explained by the fact that the forest plot is mostly composed of a dense root network with only little soil. The water can probably not be stored at this place justifying the low values of soil moisture measured.

However, the tropical climate can justify the fact that this site presents the highest values of soil moisture at its grassland plot and the highest number of measurements reaching the potential soil moisture value to initiate recharge. The fact that high values of soil moisture are 

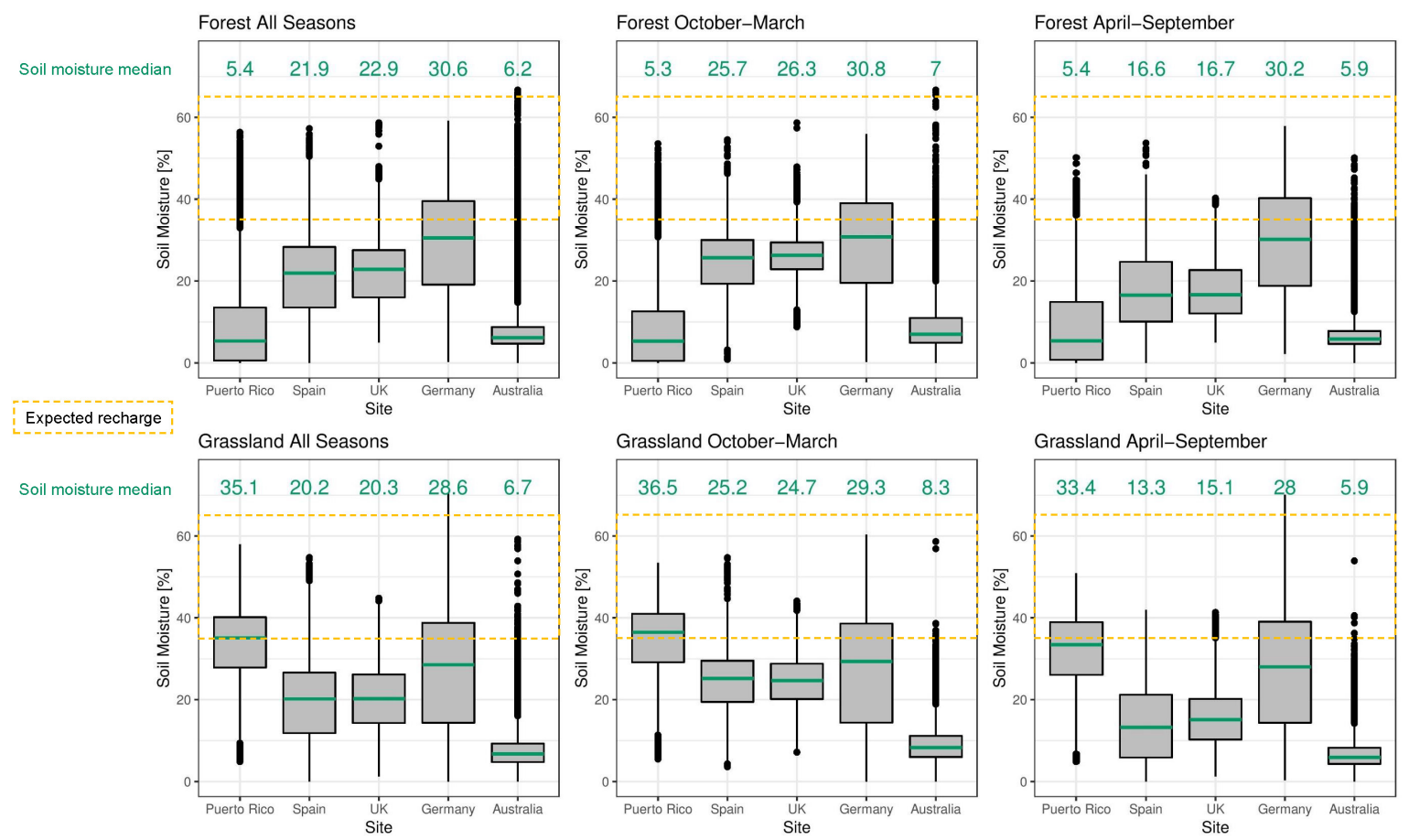

Figure 3. Boxplot of the soil moisture measurements at each site depending on the land cover and the season. A range of soil moisture value from $35 \%$ to $65 \%$ at which recharge is expected is represented within the yellow frame.

measured at the German site also can be justified with the climate has a high annual precipitation is recorded there. The Australian site, with its semi-arid climate shows only a few measurements reaching the threshold to create potential recharge. This is coherent with results presented in a preliminary analysis comparing soil moisture dynamics and drip dynamics in a cave at the Australian site. ${ }^{1}$ The recharge at this site is measured counting the drips falling into a cave below the plots. During the measured period, only one rainfall event, creating the highest soil moisture value, initiated recharge into the system. The rest of the time, the rainfall was either evaporate or used by the vegetation.

The similarities between the sites in Spain and England are quite surprising regarding their different climates. We have to consider that many other parameters can influence soil moisture reaction, as soil moisture antecedent conditions, soil texture, and vegetation (e.g., Fu et al., 2015; Heilman et al., 2012; Martos-Rosillo et al., 2015; Perrin et al., 2003). The comparison between sites and so climates remains qualitative.

In the presented study, the description of the time series results remains visual. Analyses of soil moisture reac- tions to precipitation events should be conducted individually. This would allow the extraction of parameters and thus the characterization of each soil moisture reaction. These characteristics could allow a better understanding of the infiltration processes at a small scale and a comparison of behavior between profiles and sites.

Other investigation as the comparison of measured depths should be conducted. Have the deepest probes similar values than the upper ones? Are these disparities between values, as at the German site, due to heterogeneities between the different soil horizons or because of heterogeneities within the area?

Finally, the comparison of the soil moisture between seasons should be done at different periods on at least two hydrological years. Seasons could be adapted to each site. Moreover, the choice of threshold to initiate recharge remains theoretical and could be adapted to each site depending on their soil description.

'https://blogs.agu.org/waterunderground/2019/09/25/ groundwater-and-a-green-drought/ 


\section{Conclusions and Outlook}

We use soil moisture observations to understand groundwater recharge in karstic areas at five contrasting climates and two different land use types (forest $\&$ grassland).

A difference of soil moisture behavior at almost each site is observed, but the present analysis shows nearly no differences between the forest and grassland areas. The site of Puerto Rico presents at the grassland plot the highest number of soil moisture measurements leading potentially to recharge. However, its forest plot presents the lowest, which can be explained by the large roots network in the soil of the forest. This is the only site where a difference between land uses can be observed with the conducted analyses. Other patterns as the fact that the Australian site presents the lowest number of soil moisture measurements creating potential recharge is concordant with the climate conditions. In addition, the fact that the German site presents the second-highest potential recharge confirms that climate seems to be an explanation for these behaviors. However, the sites of Spain and England present similar values. Here their different climates cannot explain their similar soil moisture measurements.

Indeed, many other parameters can influence recharge processes through the soil and epikarst. In order to explore other parameters, individual analyses of soil moisture reactions to precipitation events will be done.

Based on previous work exploring soil moisture at non-karstic region (Demand et al., 2019), an automatic method to extract events and associated parameters could allow, for example, the inclusion of antecedent soil moisture conditions and rainfall characteristics in the analyses. The analyses of soil moisture events could also allow the identification of different behavior between forest and grassland. Moreover, the comparison of soil moisture reactions to the spring signal of the studied system will allow linking soil moisture measurement to identified groundwater recharge periods.

\section{References}

Behrensmeyer AK, Darmuth JD, DiMichele WA, Pots R, Sues HD, Wing SL. 1992. Terrestrial Ecosystems through Time. Chicago, IL: The University of Chicago Press.
Beinroth FH, Engel RJ, Lugo JL, Santiago CL, Ríos S, Brannon GR. 2003. Updated Taxonomic Classification of the Soils of Puerto Rico, 2002. Bull. 303, Univ. Puerto Rico, Agric. Experiment Station, Río Piedras, P.R.

Berthelin R, Rinderer M, Andreo B, Baker A, Kilian D, Leonhardt G, Lotz A, Lichtenwoehrer K, Mudarra M, Padilla IY, Pantoja Agreda F, Rosolem R, Vale A, Hartmann A. A soil moisture monitoring network to characterize karstic recharge and evapotranspiration at five representative sites across the globe. Geosci. Instrum. Method. Data Syst. Discuss. https://doi.org/10.5194/gi-2019-22, in review, 2019.

Berthelin R, Hartmann A. 2020. The Shallow Subsurface of Karst Systems: Review and Directions. In Machine Learning for Cyber Physical Systems, edited by Jürgen Beyerer, Alexander Maier, and Oliver Niggemann, 11:61-68. Berlin, Heidelberg: Springer Berlin Heidelberg. https://doi.org/10.1007/978-3-03014015-1 7.

Charlier JB, Bertrand C, Mudry J. 2012. Conceptual Hydrogeological Model of Flow and Transport of Dissolved Organic Carbon in a Small Jura Karst System. Journal of Hydrology 460-461 (August): 52-64. https://doi.org/10.1016/j. jhydrol.2012.06.043.

Demand D, Blume T, Weiler M. Relevance and Controls of Preferential Flow at the Landscape Scale. Hydrology and Earth System Sciences Discussions, February, 1-37, https://doi. org/10.5194/hess-2019-80. 2019.

Fonseca da Silva J. 2014. Species Composition, Diversity and Structure of Novel Forests of Castilla Elastica in Puerto Rico. 14.

Ford D, Williams PD. 2013. Karst Hydrogeology and Geomorphology. John Wiley \& Sons.

Fu ZY, Chen HS, Zhang W, Xu QX, Wang S, Wang KL. 2015. Subsurface Flow in a Soil-Mantled Subtropical Dolomite Karst Slope: A Field Rainfall Simulation Study. Geomorphology 250 (December): 1-14. https://doi.org/10.1016/j. geomorph.2015.08.012. 
Garvelmann J, Warscher M, Leonhardt G, Franz H, Lotz A, Kunstmann H. 2017. Quantification and Characterization of the Dynamics of Spring and Stream Water Systems in the Berchtesgaden Alps with a Long-Term Stable Isotope Dataset. Environmental Earth Sciences 76 (22). https://doi. org/10.1007/s12665-017-7107-6.

Giese M, Reimann T, Bailly-Comte V, Maréchal J-C, Sauter M, Geyer T. 2018. Turbulent and Laminar Flow in Karst Conduits Under Unsteady Flow Conditions: Interpretation of Pumping Tests by Discrete Conduit-Continuum Modeling. Water Resources Research 54 (3): 1918-33. https://doi. org/10.1002/2017WR020658.

Goldscheider N, Drew D. 2007. Methods in Karst Hydrogeology. Taylor \& Francis Group, Leiden, NL.

Goldscheider N, Meiman J, Pronk M, Smart C. 2008. Tracer Tests in Karst Hydrogeology and Speleology. International Journal of Speleology 37 (1): 27-40. https://doi.org/10.5038/1827$\underline{806 X .37 .1 .3}$.

Hartmann A, Baker A. 2017. Modelling karst vadose zone hydrology and its relevance for paleoclimate reconstruction. Earth-Science Rev. 1-54. https:// doi.org/10.1016/j.earscirev.2017.08.001.

Heilman JL, Litvak ME, McInnes KJ, Kjelgaard JF, Kamps RH, Schwinning S. 2012. Water-storage Capacity Controls Energy Partitioning and Water Use in Karst Ecosystems on the Edwards Plateau, Texas. Ecohydrology 7 (1): 127-38. https://doi. org/10.1002/eco.1327.

Iwema J. 2017. Opportunities and Limitations of the Cosmic-Ray Neutron Soil Moisture Sensor under Humid Conditions'. University of Bristol.

Jex C, Mariethoz G, Baker A, Graham P, Andersen M, Acworth I, Edwards N, Azcurra C. 2012. Spatially Dense Drip Hydrological Monitoring and Infiltration Behaviour at the Wellington Caves, South East Australia. International Journal of Speleology 41 (2): 283-96. https://doi. org/10.5038/1827-806X.41.2.14.

Keshavarzi M, Baker A, Kelly BFJ, Andersen MS. 2017. River-Groundwater Connectivity in a Karst System, Wellington, New South Wales, Australia.
Hydrogeology Journal 25 (2): 557-74. https://doi. org/10.1007/s10040-016-1491-y.

Kirn L, Mudarra M, Marín A, Andreo B. 2017. Improved Assessment of Groundwater Recharge in a Mediterranean Karst Region - Andalusia, Spain. In Conference Proceedings of EuroKarst 2016. Neuchatel (CH), pp. 117-125. https://doi. org/10.1007/978-3-319-45465-8.

Kraller G, Strasser U, Franz H. 2011. Effect of Alpine Karst on the Hydrology of the Berchtesgadener Ache Basin: A Comprehensive Summary of Karst Research in the Berchtesgaden Alps', eco.mont, 3 (1): 19-28.

Lugo AE, Castro LM, Vale A, López TM, Prieto EH, Martinó AG, Rolón ARP, Tossas AG, McFarlane DA, Miller T, Rodríguez A, Lundberg J, Thomlinson J, Colón J, Schellekens JH, Ramos O, Helmer E. Puerto Rican Karst-A Vital Resource. United States Department of Agriculture Forest Service General Technical Report WO-65, 2001.

Maloszewski P, Stichler W, Zuber A, Rank D. 2002. Identifying the Flow Systems in a KarsticFissured-Porous Aquifer, the Schneealpe, Austria, by Modelling of Environmental ${ }^{18} \mathrm{O}$ and ${ }^{3}$ H Isotopes'. Journal of Hydrology, 256 (1-2): 48-59.

Marín AI, Andreo B, Mudarra M. 2015. Vulnerability Mapping and Protection Zoning of Karst Springs. Validation by Multitracer Tests. Science of The Total Environment 532 (November): 435-46. https://doi.org/10.1016/j.scitotenv.2015.05.029.

Markowska M, Baker A, Andersen MS, Jex CN, Cuthbert MO, Rau GC, Graham PW, et al. 2016. Semi-Arid Zone Caves: Evaporation and Hydrological Controls on $\Delta 180$ Drip Water Composition and Implications for Speleothem Paleoclimate Reconstructions'. Quaternary Science Reviews 131 (January): 285-301. https:// doi.org/10.1016/j.quascirev.2015.10.024.

Martos-Rosillo S, González-Ramón A, Jiménez-Gavilán P, Andreo B, Durán JJ, Mancera E. 2015. Review on Groundwater Recharge in Carbonate Aquifers from SW Mediterranean (Betic Cordillera, S Spain). Environmental Earth Sciences 74 (12): 7571-81. https://doi.org/10.1007/s12665-0154673-3. 
Mudarra M, Andreo B, Marín AI, Vadillo I, Barberá JA. 2014. Combined Use of Natural and Artificial Tracers to Determine the Hydrogeological Functioning of a Karst Aquifer: The Villanueva Del Rosario System (Andalusia, Southern Spain)'. Hydrogeology Journal 22 (5): 1027-39. https:// doi.org/10.1007/s10040-014-1117-1.

Perrin J, Jeannin PY, Zwahlen F. 2003. Epikarst Storage in a Karst Aquifer: A Conceptual Model Based on Isotopic Data, Milandre Test Site, Switzerland'. Journal of Hydrology 279 (1): 106-24. https://doi. org/10.1016/S0022-1694(03)00171-9.

Peyre Y. 1974. Géologie D'Antequera et de Sa Région (Cordillères Bétiques, Espagne). Paris: University. of Paris.

Rahman M, Rosolem R. 2017. Towards a Simple Representation of Chalk Hydrology in Land Surface Modelling. Hydrology and Earth System Sciences 21 (1): 459-71. https://doi.org/10.5194/ hess-21-459-2017.

Ries F, Lange J, Schmidt S, Puhlmann H, Sauter M. 2015. Recharge Estimation and Soil Moisture Dynamics in a Mediterranean, Semi-Arid Karst Region. Hydrology and Earth System Sciences 19 (3): 1439-56. https://doi.org/10.5194/hess-191439-2015.

Rivera-Sostre ML. 2008. Variación En La Dieta Del Sapo de La Caña (Chaunus [Bufo] Marinus) En La Reserva Natural Privada El Tallonal En Arecibo, Puerto Rico'. Tesis Maestria.

Sarrazin F, Hartmann A, Pianosi F, Wagener T. 2018. V2Karst V1.1: a parsimonious large-scale integrated vegetation-recharge model to simulate the impact of climate and land cover change in karst regions. Geosci. Model Dev. 11, 4933-4964. https://doi.org/10.5194/gmd-2017-315.

Seiglie GA, Moussa MT. 1984. Late OligocenePliocene Transgressive Regressive Cycles of Sedimentation in Northwestern Puerto Rico. In Interregional Unconformities and Hydrocarbon Accumulation'. J.S. Schlee, Editor. American Association of Petroleum Geologists Memoir 36, 89-98.

Trček B. 2007. How Can the Epikarst Zone Influence the Karst Aquifer Hydraulic Behaviour?
Environmental Geology 51 (5): 761-65. https:// doi.org/10.1007/s00254-006-0387-x.

Troester JW. 1999. Geochemistry and Hydrogeologic Framework of the Saline-Freshwater Interface and the Calculation of the Net Recharge in the Dorado Area, North-Central Puerto Rico. Water Resources Investigations Report 98- 4030. San Juan, PR: US Geological Survey.

Viera Martinez CA, Abelleira O, Lugo AE. 2008. Estructura y química del suelo en un bosque de Castilla elastica en el carso del norte de Puerto Rico: resultados de una calicata, Acta Científica, 22(1-3):29-35.

Vörösmarty CJ, McIntyre PB, Gessner MO, Dudgeon D, Prusevich A, Green P, Glidden S, et al. 2010. Global Threats to Human Water Security and River Biodiversity. Nature 467 (7315): 555-61. https://doi.org/10.1038/nature09440.

Wada Y, van Beek LPH, van Kempen CM, Reckman JWTM, Vasak S, Bierkens MFP. 2010. Global Depletion of Groundwater Resources: GLOBAL GROUNDWATER DEPLETION. Geophysical Research Letters 37 (20). https://doi. org/10.1029/2010GL044571.

Wheater HS, Peach D, Binley A. 2007. Characterising Groundwater-Dominated Lowland Catchments: The UK Lowland Catchment Research Programme (LOCAR). Hydrology and Earth System Sciences 11 (1): 108-24. https://doi. org/10.5194/hess-11-108-2007.

Williams PW. 1983. The Role of the Subcutaneous Zone in Karst Hydrology'. Journal of Hydrology, V.T. Stringfield Symposium - Processes in Karst Hydrology, 61 (1): 45-67. https://doi. org/10.1016/0022-1694(83)90234-2.

Zhang Z, Chen X, Chen X, Shi P. 2013. Quantifying Time Lag of Epikarst-Spring Hydrograph Response to Rainfall Using Correlation and Spectral Analyses. Hydrogeology Journal 21 (7): 1619-31. https://doi.org/10.1007/s10040-013$\underline{1041-9}$. 